RESEARCH PAPER RP1191

Part of Journal of Research of the National Bureau of Standards, Volume 22, April 1939

\title{
ACTION OF BAKER'S YEAST ON $d$-TALOSE
}

\author{
By Horace S. Isbell
}

\section{ABSTRACT}

It is shown that baker's yeast does not acquire the property of fermenting talose by growing on galactose- and talose-containing media.

\section{CONTENTS}

I. Introduction

Page

403

II. Preparation of yeast.

III. Action of the "galactose yeast" and the "talose yeast" on solutions of glucose, galactose, and talose

\section{INTRODUCTION}

The four hexoses, $d$-glucose, $d$-mannose, $d$-fructose, and $d$-galactose are fermented by yeasts. Kinetic studies, made with different yeasts and different temperatures have shown that glucose, mannose, and fructose are fermented with approximately the same readiness. Many yeasts which ferment glucose are without action on galactose and the temperature coefficients and properties of the fermentation of galactose show that it is different from the fermentation of glucose. If the similar behavior of the epimeric sugars, glucose and mannose, is due to the rapid formation of a common intermediate substance during the fermentation, one might anticipate that $d$-talose, which is epimeric to $d$-galactose, would be fermented by the same yeasts which act on galactose. It is reported, however, that $d$-talose is not fermentable. This important observation was made with crude talose solutions before crystalline talose was available. ${ }^{1}$ Since a quantity of pure crystalline $d$-talose had been prepared in this laboratory, ${ }^{2}$ it seemed desirable to reinvestigate the subject.

Yeasts which do not ordinarily ferment galactose acquire the property of fermenting it by growth in a galactose-containing medium. In order to ascertain whether or not a talose-fermenting yeast could be obtained by growth in a talose-containing medium, a series of fermentations with baker's yeast was conducted under conditions similar to those which Kirby and Atkin ${ }^{3}$ found suitable for the preparation of

\footnotetext{
${ }^{1} \mathrm{~J}$. v. Braun and O. Bayer, Ber. deit. chem. Ges. 58, 2215 (1925). E. Fischer and H. Thierfelder, Ber. deut. chem. Ges. 27, 2031 (1894)

2 W. W. Pigman and H. S. Isbell, J. Research NBS 19, 189 (1937) RP1021.

$3 \mathrm{G}$. W. Kirby and L. Atkin, J. Biol. Chem. 116, 511 (1936).
} 
galactose-fermenting yeasts. The results were negative so far as the production of a talose-fermenting yeast is concerned. Even after growing three generations in the presence of talose, the yeast did not appear to have talose-fermenting properties.

\section{PREPARATION OF YEAST}

Ten-milliliter portions of a solution containing $2.5 \mathrm{~g}$ of glucose, $2.5 \mathrm{~g}$ of galactose, and $1.5 \mathrm{~g}$ of yeast extract in $100 \mathrm{ml}$ of water were placed in test tubes and sterilized by heating for 30 minutes in a steam autoclave at $110^{\circ} \mathrm{C}$. This sterile solution is hereafter designed as the galactose medium. A sample of baker's yeast (Fleischmann's) was introduced into one of the test tubes containing the galactose medium and the mixture was incubated at $30^{\circ} \mathrm{C}$. After 2 days the yeast was separated and introduced into a second tube containing $10 \mathrm{ml}$ of the galactose medium and incubated again for 2 days, after which the yeast was transferred to a third tube containing $10 \mathrm{ml}$ of the galactose medium and incubated a third time. The resulting yeast was decanted and washed with sterile water. This product was the "galactose yeast" used in the experiment reported in table 1.

A sterile solution containing $2.5 \mathrm{~g}$ of glucose, $2.5 \mathrm{~g}$ of $d$-talose, and $1.5 \mathrm{~g}$ of yeast extract in $100 \mathrm{ml}$ of water was prepared and the process used for growing the galactose yeast was repeated with this solution as a medium. The growth of yeast was smaller than that obtained with the galactose medium, but appeared healthy. The product thus obtained was designated "talose yeast," even though it does not appear to have any talose-fermenting property.

\section{ACTION OF THE "GALACTOSE YEAST" AND THE "TALOSE YEAST" ON SOLUTIONS OF GLUCOSE, GALAC- TOSE, AND TALOSE}

The galactose and talose yeasts obtained as described in the preceding paragraph were divided and introduced into solutions of glucose, galactose, and talose containing $2.5 \mathrm{~g}$ of glucose, galactose, or talose, and $2 \mathrm{ml}$ of a nutrient solution per $100 \mathrm{ml}$. The nutrient solution contained $2.5 \mathrm{~g}$ of $\mathrm{NH}_{4} \mathrm{NO}_{3}, 0.3 \mathrm{~g}$ of $\mathrm{KH}_{2} \mathrm{PO}_{4}$, and $0.25 \mathrm{~g}$ of $\mathrm{MgSO}_{4^{-}}$ $7 \mathrm{H}_{2} \mathrm{O}$ per $100 \mathrm{ml}$. The solutions were incubated at $30^{\circ} \mathrm{C}$ and from time to time $10-\mathrm{ml}$ portions were separated for optical-rotation measurements Before reading the samples the solutions were clarified by treating with $10 \mathrm{mg}$ of normal lead acetate. After the samples stood for 2 hours at $20^{\circ} \mathrm{C}$, they were read on a Bates' saccharimeter in a 2 -dm tube.

Although both yeasts fermented glucose and galactose, neither yeast fermented $d$-talose. The galactose-fermenting property of the "talose yeast" was not necessarily acquired because the original baker's yeast had a small galactose-fermenting capacity. After the fermentation had been allowed to continue for 15 days, nearly all of the talose was reclaimed in the crystalline state from the residual liquors. 
TABLE 1.-Action of yeasts on solutions of d-talose, $d$-galactose, and d-glucose at $30^{\circ} \mathrm{C}$

\begin{tabular}{|c|c|c|c|c|c|}
\hline \multirow[b]{2}{*}{ Time } & \multirow{2}{*}{$\frac{d \text {-Talose }}{\begin{array}{c}\text { Optical } \\
\text { rotation in } \\
2 \text {-dm tube }\end{array}}$} & \multicolumn{2}{|c|}{$d$-Galactose } & \multicolumn{2}{|c|}{$d$-Glucose } \\
\hline & & $\begin{array}{l}\text { Optical } \\
\text { rotation in } \\
2 \text {-dm tube }\end{array}$ & $\begin{array}{l}\text { Porcentage } \\
\text { of sample } \\
\text { fermented }\end{array}$ & $\begin{array}{l}\text { Optical } \\
\text { rotation in } \\
2 \text {-dm tube }\end{array}$ & $\begin{array}{l}\text { Percentage } \\
\text { of sample } \\
\text { fermented }\end{array}$ \\
\hline \multicolumn{6}{|c|}{ GALACTOSE YEAST } \\
\hline 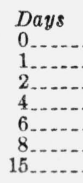 & $\begin{array}{l}{ }^{\circ} S \\
2.90 \\
2.94 \\
2.88 \\
2.88 \\
3.02 \\
2.96 \\
2.95\end{array}$ & $\begin{array}{l}{ }^{\circ} \mathrm{S} \\
11.80 \\
10.46 \\
9.09 \\
6.52 \\
3.30 \\
0.11 \\
(\mathrm{a})\end{array}$ & $\begin{array}{l}0 \\
11.4 \\
23.0 \\
44.8 \\
72.0 \\
99.1 \\
100\end{array}$ & $\begin{array}{l}{ }^{\circ} S \\
7.00 \\
5.30 \\
3.55 \\
0.50 \\
(\mathbf{a})\end{array}$ & $\begin{array}{c}0 \\
24.3 \\
49.3 \\
92.9 \\
100\end{array}$ \\
\hline \multicolumn{6}{|c|}{ TALOSE YEAST } \\
\hline 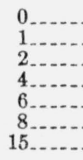 & $\begin{array}{l}3.02 \\
2.96 \\
3.02 \\
2.94 \\
2.95 \\
2.94 \\
3.00\end{array}$ & $\begin{array}{l}11.85 \\
11.60 \\
11.53 \\
10.10 \\
6.92 \\
2.14 \\
(\mathrm{~s})\end{array}$ & $\begin{array}{r}0 \\
2.1 \\
2.7 \\
14.8 \\
41.6 \\
81.9 \\
100\end{array}$ & $\begin{array}{l}7.03 \\
6.67 \\
4.91 \\
0.95 \\
(\mathbf{s})\end{array}$ & $\begin{array}{c}0 \\
5.1 \\
30.2 \\
86.5 \\
100 \\
\end{array}$ \\
\hline
\end{tabular}

n Test for reducing sugar was negative.

Washington, February 10, 1939. 